\title{
A new subgenus of the genus Pbytoecia Dejean, 1835 (Coleoptera: Cerambycidae: Lamiinae)
}

\author{
Новый подрод из рода Pbytoecia Dejean, 1835 \\ (Coleoptera: Cerambycidae: Lamiinae)
}

\author{
D.G. Kasatkin \\ А.Г. Касаткин
}

Rostov branch of FSI "VNIIKR", 20 th line, 43/16, Rostov-on-Don 344018, Russia. E-mail: kassatkind@mail.ru Ростовское отделение ФГБУ “ВНИИКР”, 20-я линия, 43/16, Ростов-на-Дону 344018, Россия.

KEYWORDS: Coleoptera, Cerambycidae, Phytoecia, Coptosia, new subgenus, endophallus.

КЛЮЧЕВЫЕ СЛОВА: Coleoptera, Cerambycidae, Phytoecia, Coptosia, новый подрод, эндофаллус.

ABSTRACT. The new subgenus Coptosiella subgen.n. of the genus Phytoecia Dejean, 1835 (earlier including in the subgenus Coptosia Fairmaire) with the type species Phytoecia antoniae Reitter, 1889 is described. Diagnostic characters of external morphology and structure of genitalia of the both subgenera are given.

РЕЗЮМЕ. ОПисывается новый подрод Сорtosiella subgen.n. из рода Phytoecia Dejean, 1835 с типовым видом Phytoecia antoniae Reitter, 1889, ранее включавшимся в подрод Coptosia Fairmaire, 1864. Перечислены признаки внешней морфологии и гениталий самца, различающие эти подроды.

\section{Introduction}

The subgenus Coptosia Fairmaire, 1864 includes 12 species and subspecies distributed in Southern Europe, Transcaucasia and Middle East. Part of subgenera of the genus Phytoecia Dejean, 1835 including Coptosia are considered as genera [Catalogue..., 2010], but in this paper the taxon Phytoecia is considered as genus sensu lato until the final clarification of its taxonomic structure. All known species of Coptosia has similar habitus with longitudinal striped pattern and long erect hairs on dorsal surface of a body. However, Ph. antoniae Reitter, 1889 is distinctly different from all other species of the subgenus even habitually. Ph. antoniae deserves to be distinguished in the separate subgenus Coptosiella subgen.n. considering number of important characters of inner morphology and male genitalia.

\section{Material and methods}

The study is based on the examination of adult beetles from the following private collections, institutes and museums: private collection of Dr. A.I.Miroshnikov
(Krasnodar, Russia), National Museum of Prague (Czech Republic, Prague), Zoological Museum of Moscow University (Russia, Moscow), Natural History Museum of Vienna (Austria, Vienna), Bavarian State Collection of Zoology (Munich, Germany), Zoological Museum of Humboldt University (Berlin, Germany).

Specimens were examined with Olympus SZ61 stereomicroscopes. The photographs were taken with a Canon MP-E $65 \mathrm{~mm} / 2.8$ on bellows attached to a Canon EOS 5D Mark III camera and Olympus SP 350 mounted on Olympus CX41 microscopes. Partially focused images were stacked using the Helicon Focus Pro v5.3.14 software.

Preparations of everted and inflated endophallus were made according to the procedure described in Kasatkin [2006].

\section{Taxonomical part}

Coptosiella Kasatkin subgen.n.

Figs 1, 16-17, 23, 27-28

Type species Phytoecia antoniae Reitter, 1889.

DESCRIPTION. Body lenght: 12-15 mm. Body black, dense covered with recumbent pubescence. Head dense covered with recumbent pubescence and brown erect hairs; mandibles elongated, without tooth. Antennae short, robust, reaching last elytral third, covered with dense pubescence, antennomers not annulated on base.

Pronotum transverse, angularly extended to middle; punctation not coarse and moderately dense, with distinct microsculpture, pronotal disc with two small shine callosities (Fig. 1).

Elytrae elongated, with distinct shoulders, much wider at shoulders than at apex, flat on disc, truncated on apex. Dorsal surface of elytra and pronotum without long erect hairs, entirely covered with homogenous gray pubescence (Figs 1, 23) hides sculpture, longitudinal stripes absent. Punctation coarse and dense (sometimes moderately dense), elytral microsculpture presented by very small tubercles (Fig. 17). 

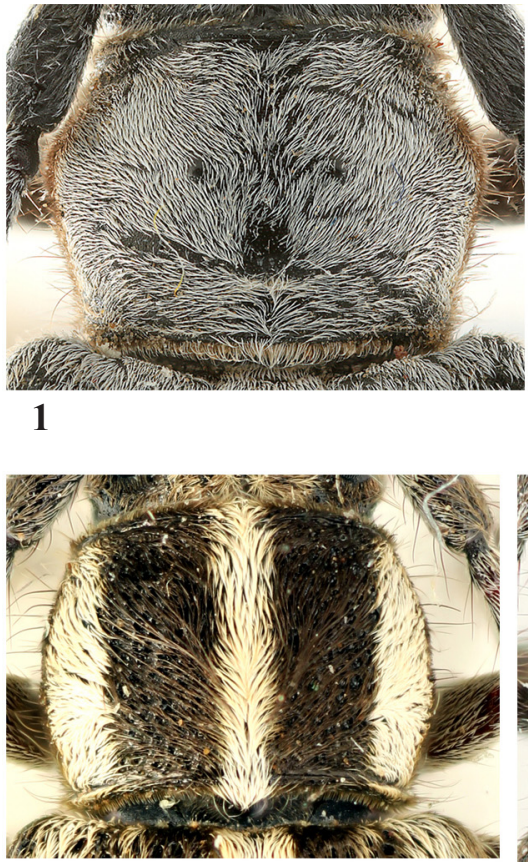

4

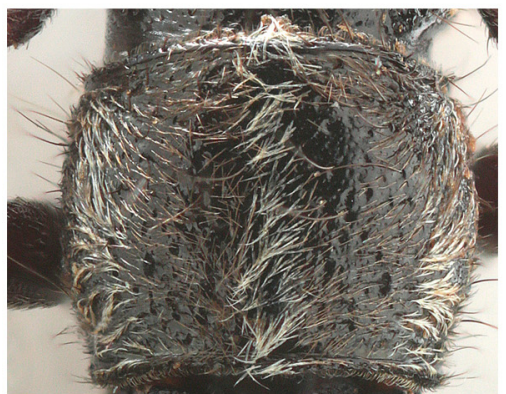

7

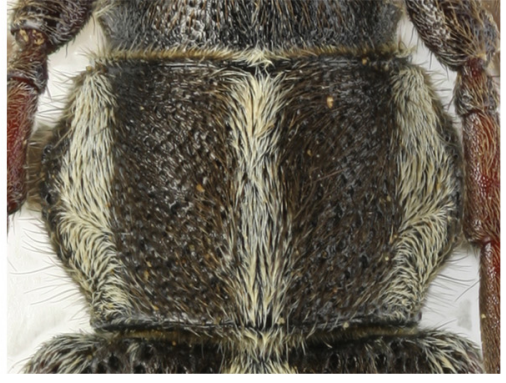

2

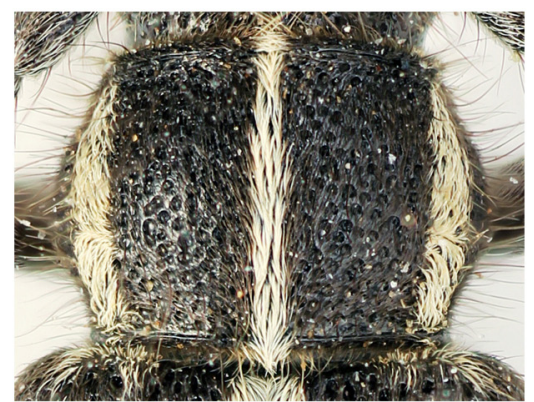

5

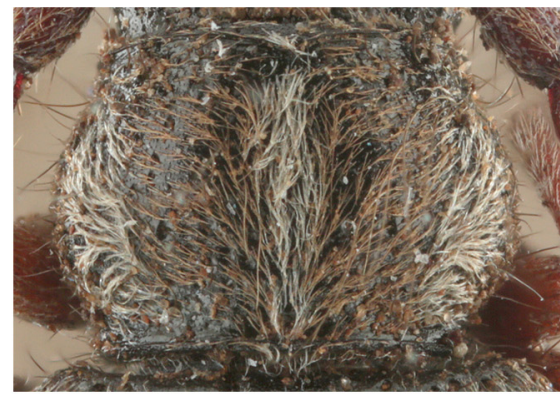

8

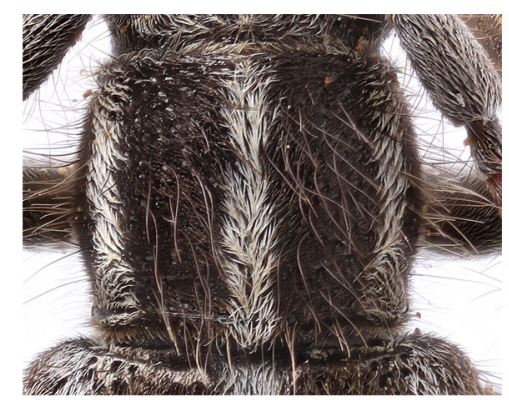

3

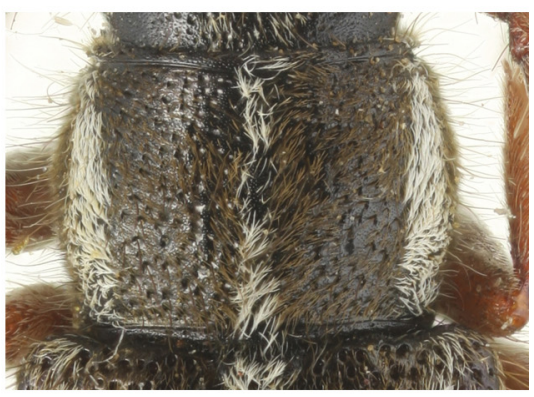

6

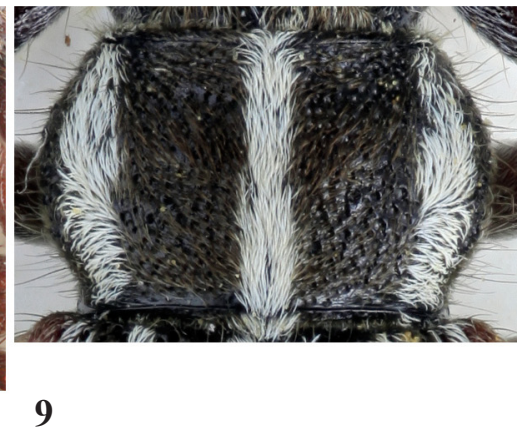

Figs 1-9. Pronotum of Coptosia and Coptosiella subgen.n.: 1 - Ph. (Coptosiella) antoniae Reitter, 1889; 2 - Ph. (Coptosia) compacta (Ménétriés, 1832); 3 - Ph. (C.) albovittigera Heyden, 1863; 4 - Ph. (C.) brunnerae (Sama, 2000); 5 - Ph. (C.) ganglbaueri Pic, 1936; 6 - Ph. (C.) bithynensis Ganglbauer, 1884; 7 - Ph. (C.) minuta Pic, 1891; 8 - Ph. (C.) schuberti Fuchs, 1965; $9-$ Ph. (C.) compacta sancta Reiche, 1877.

Рис. 1-9. Переднеспинки Coptosia and Coptosiella subgen.n.: 1 - Ph. (Coptosiella) antoniae Reitter, 1889; 2 - Ph. (Coptosia) compacta (Ménétriés, 1832); 3 - Ph. (C.) albovittigera Heyden, 1863; 4 - Ph. (C.) brunnerae (Sama, 2000); 5 - Ph. (C.) ganglbaueri Pic, 1936; 6 - Ph. (C.) bithynensis Ganglbauer, 1884; 7 - Ph. (C.) minuta Pic, 1891; 8 - Ph. (C.) schuberti Fuchs, 1965; 9 - Ph. (C.) compacta sancta Reiche, 1877.

Ventral side of the body covered with dense yellowbrown pubescence, hiding the cuticle, with brown erect hairs. Legs with dense gray pubescence; male metacoxae with short and thick tooth (Fig. 16).

Lateral lobes robust, widened to the apex; penis parallel sided, rounded apically and barely noticeable sharpened on apex. Endophallus with very large medial bulb and large ventral field of microtrichia in medial phallomer; group of apical sclerits includes only two small sclerites (Figs 27-28).

DIAGNOSIS. The new subgenus very distinctly different from other species of Coptosia by following characters: presented tooth on male metacoxae; tuberculated elytral and pronotal microsculpture; uniform colored of dorsal elytral and pronotal pubescence without erect hairs; pronotal shape; large medial phallomer of endophallus and small apical endophallic sclerits. All species of Coptosia usually cov- ered with dense long erect hairs on pronotal disc and elytra; elytra always with at the minimum light sutural stripe and nothing with unicolour elytral pubescence, pronotum with 3 light longitudinal stripes and without callosities (Figs 2-9); elytral microsculpture presented by small and not dense punctures (Fig. 18), nearly obsolete; male metacoxae without tooth (Figs 10-15); medial phallomer simple, scleritic apical group includes 5 long sclerits (Figs 24-26, 29).

COMPOSITION. Monobasic subgenus.

ACKNOWLEDGEMENTS. The author sincerely acknowledges, colleagues who provided material for study: Dr. A.A. Gusakov (Moscow, Russia), Dr. A.I. Miroshnikov (Krasnodar, Russia), Dr. H. Schilhammer (Vienna, Austria), Dr. S. Blank (Muncheberg, Germany), Dr. J.Frisch (Berlin, Germany), Dr. M. Balke (Munich, Germany), Dr. H. Hajek (Prague, Czech Republic). 


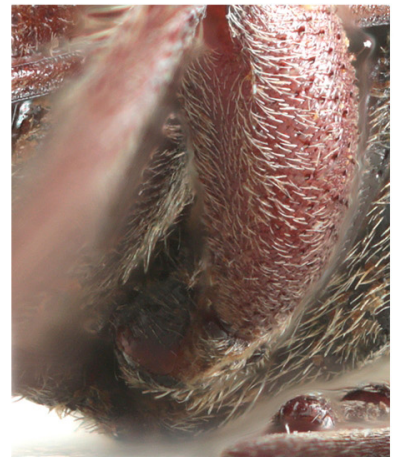

10

14

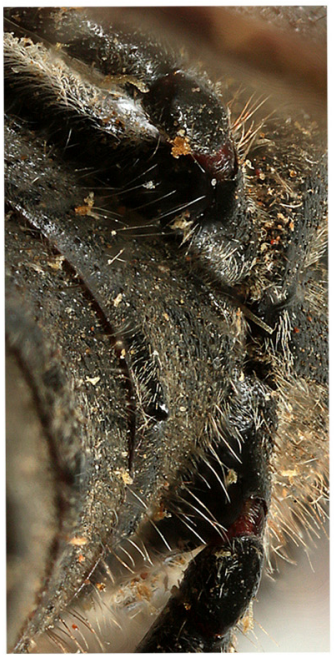

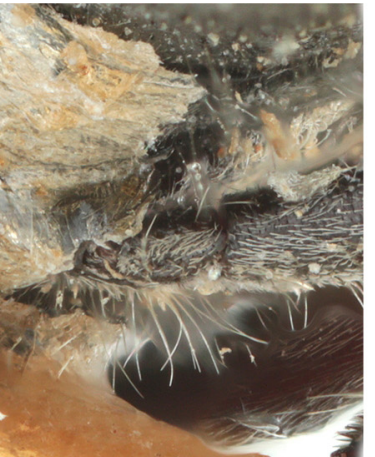

11

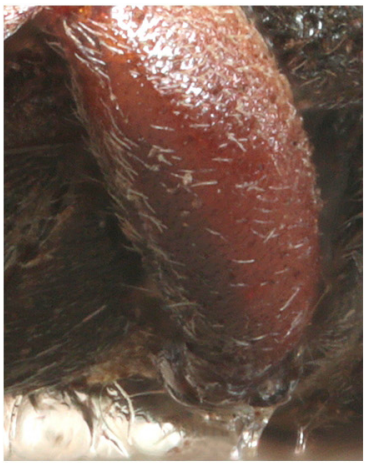

12

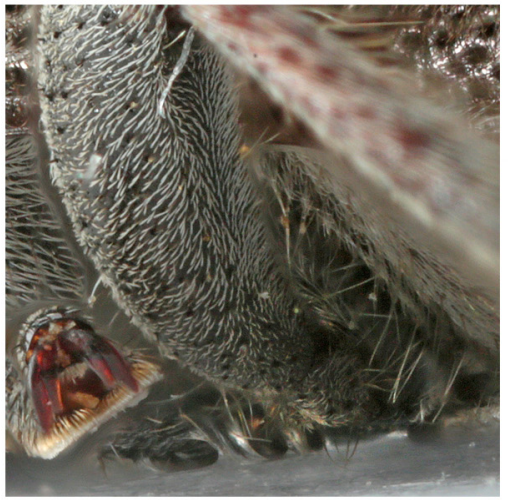

15

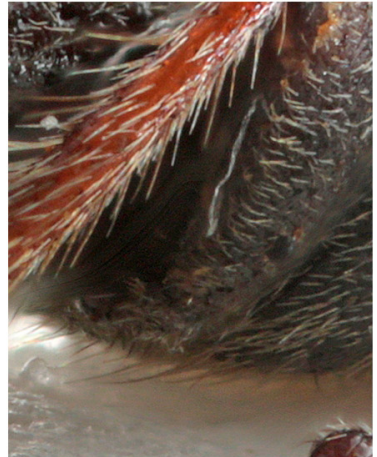

13

16

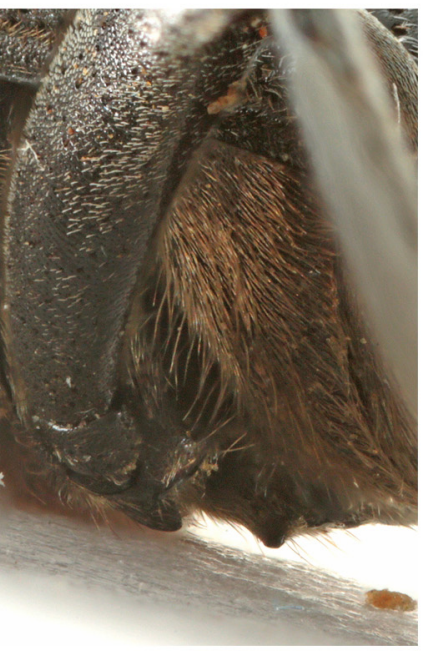

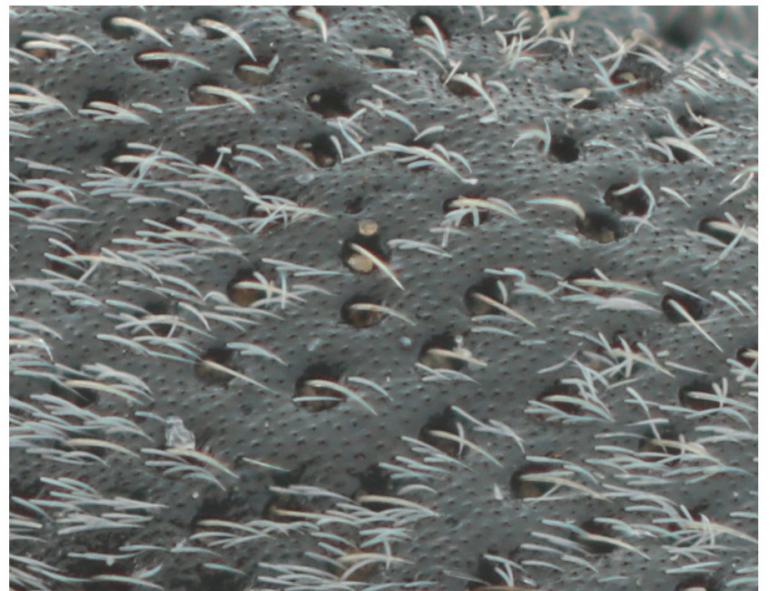

17

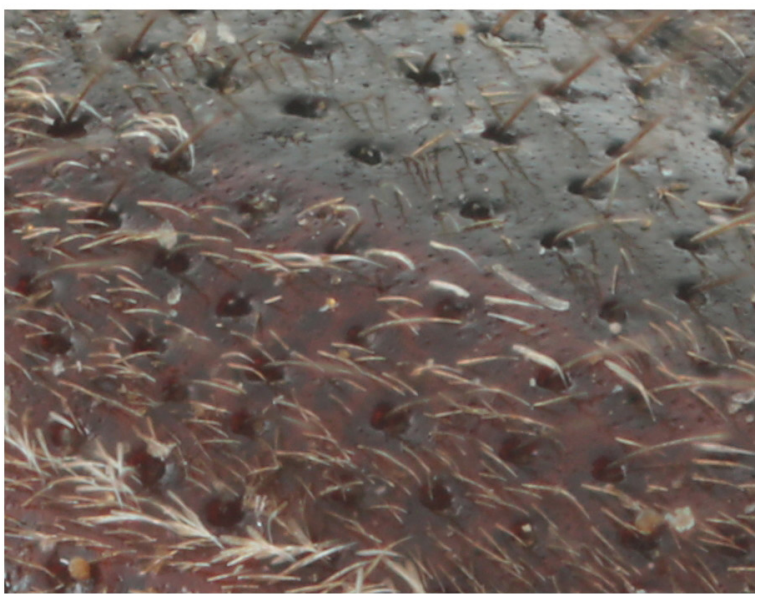

18

Figs 10-18. Detailed of morphology Coptosia and Coptosiella subgen.n.: 10, $18-$ Ph. (Coptosia) bithynensis; $11-$ Ph. (C.) ganglbaueri; $12-$ Ph. (C.) schuberti; 13 - Ph. (C.) minuta; 14 - Ph. (C.) compacta; $15-$ Ph. (C.) albovittigera; 16-17 - Ph. (Coptosiella) antoniae; 10-16 - metacoxae of male, 17-18 - microsculpture of elytra.

Рис. 10-18. Детали морфологии Coptosia and Coptosiella subgen.n.: 10, 18 - Ph. (Coptosia) bithynensis; 11 - Ph. (C.) ganglbaueri; 12 - Ph. (C.) schuberti; 13 - Ph. (C.) minuta; 14 - Ph. (C.) compacta; 15 - Ph. (C.) albovittigera; 16-17 - Ph. (Coptosia) antoniae; 10 16 - задние тазики самца, $17-18$ - микроскульптура надкрылий.

\section{References}

Catalogue of Palaearctic Coleoptera. 2010. / Lobl I., Smetana A. (eds.).Vol.6. Chrysomeloidea. Stenstrup: Apollo Books. 924 p.
Kasatkin D.G. 2006. The internal sac of aedeagus of longhorned beetles (Coleoptera: Cerambycidae): morphology, nomenclature of structures, taxonomic significance // Caucasian Entomological Bulletin. Vol.2. No.1. P.83-10 [in Russian]. 

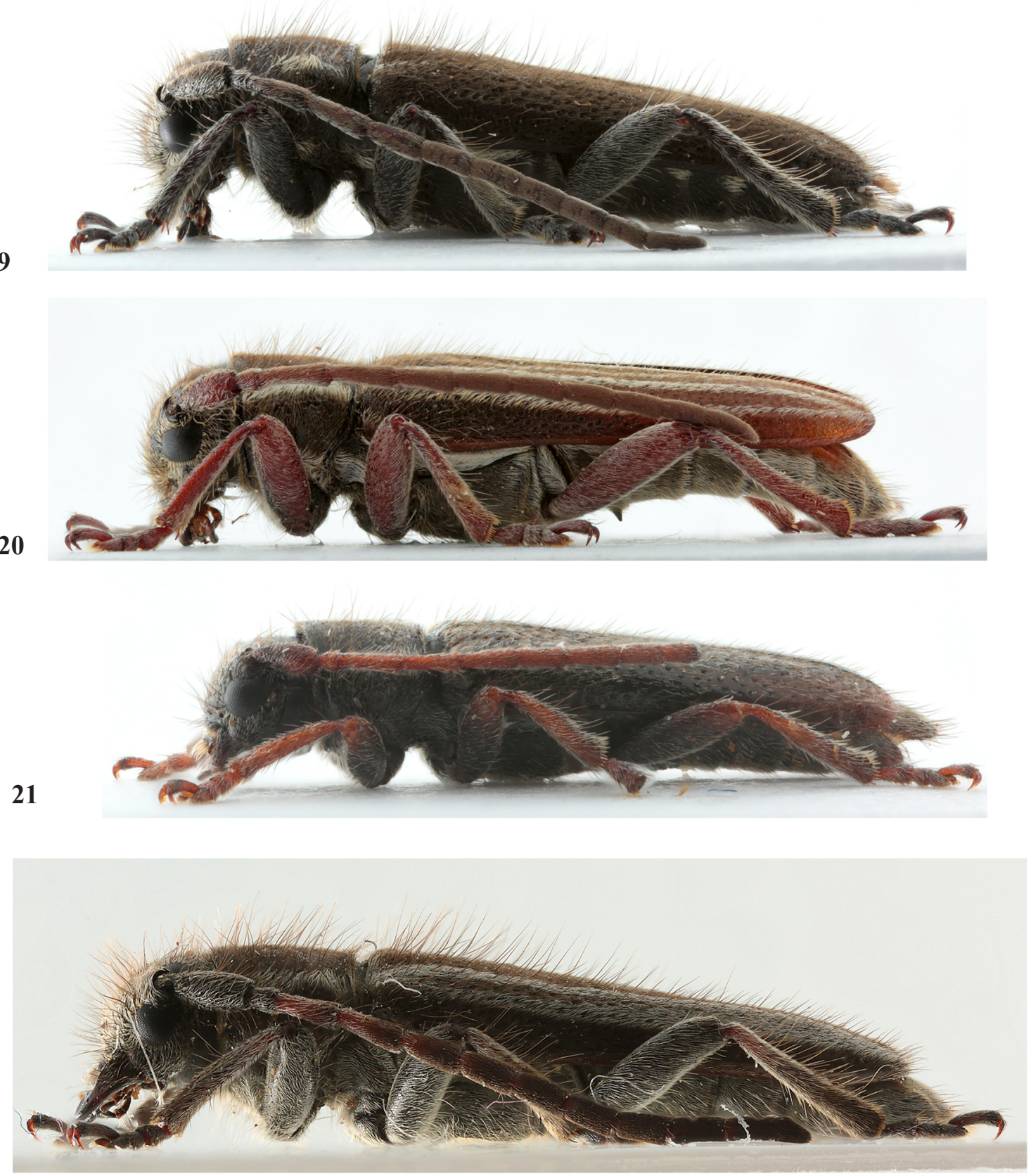

23

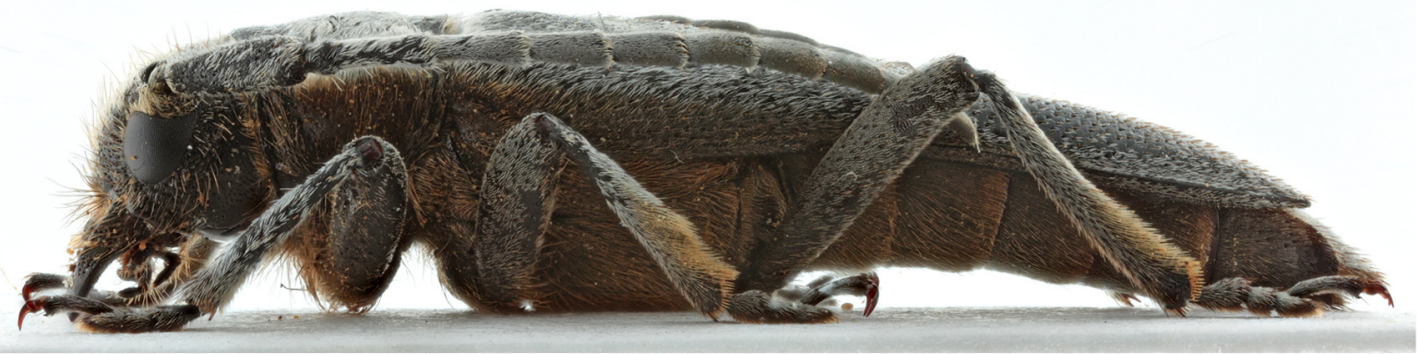

Figs 19-23. Habitus of Coptosia and Coptosiella subgen.n., lateral view: 19 - Ph. (Coptosia) ganglbaueri; 20 - Ph. (C.) bithynensis; 21 - Ph. (C.) minuta; 22 - Ph. (C.) albovittigera; 23 - Ph. (Coptosiella) antoniae.

Рис. 19-23. Внешний вид Coptosia and Coptosiella subgen.n., вид сбоку: $19-$ Ph. (Coptosia) ganglbaueri; $20-P h .(C$.) bithynensis; $21-$ Ph. (C.) minuta; $22-$ Ph. (C.) albovittigera; $23-$ Ph. (Coptosiella) antoniae. 


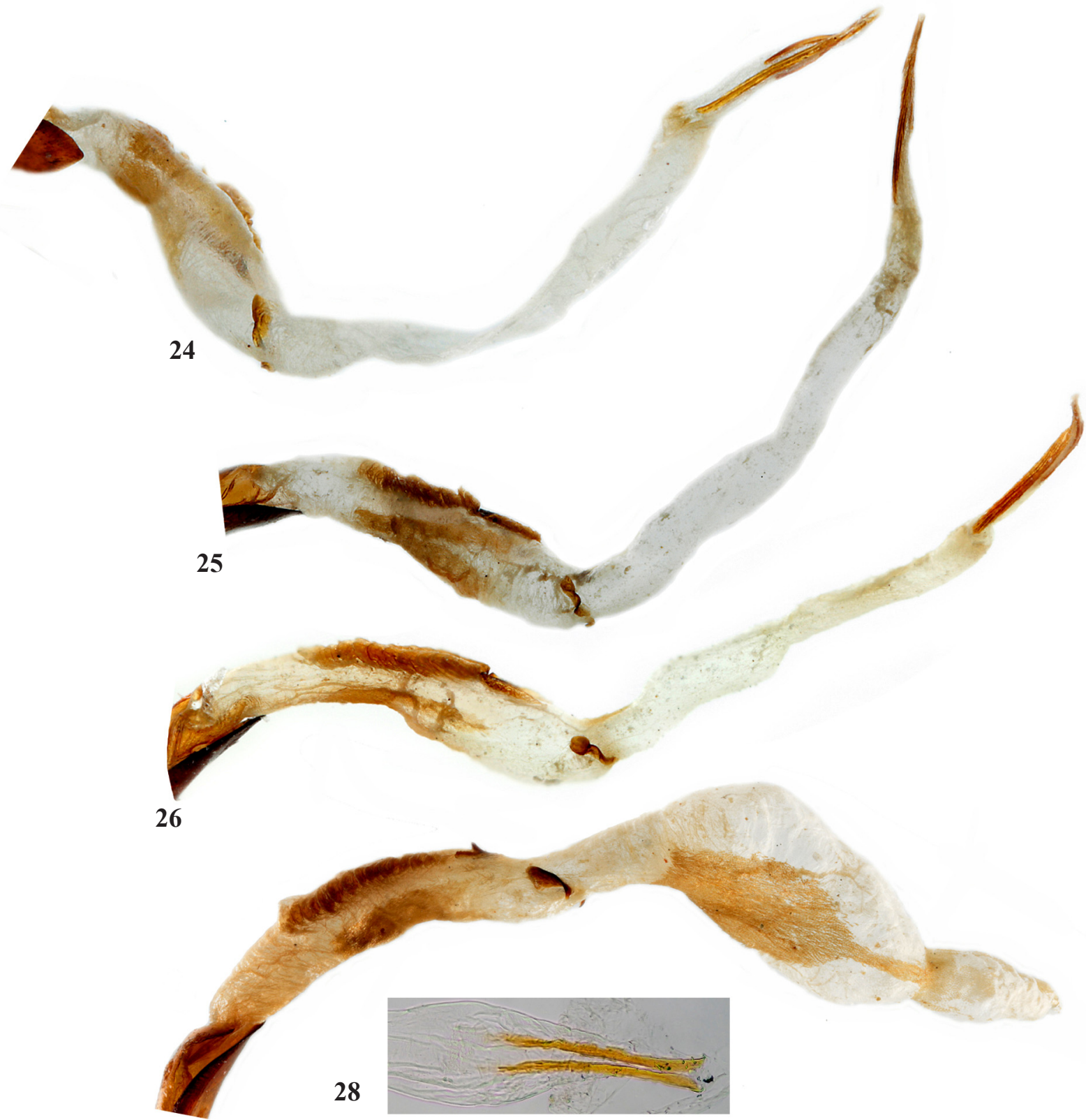

27

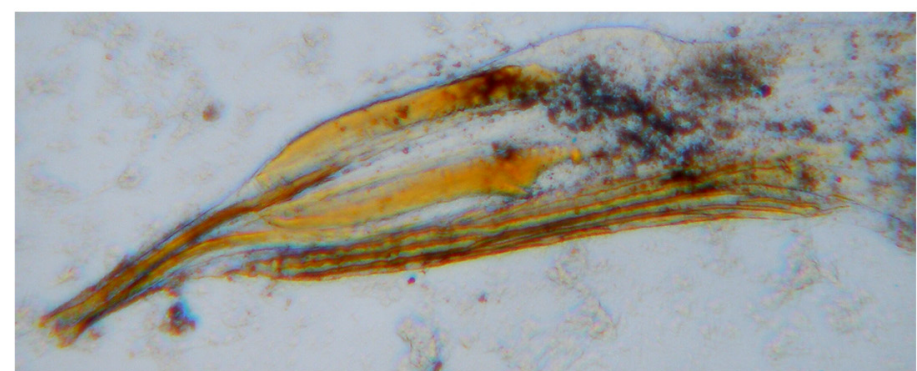

29

Figs 24-29. Endophallus of Coptosia and Coptosiella subgen.n.: 24 - Ph. (Coptosia) albovittigera; 25, 29 - Ph. (C.) compacta; 26 - Ph. (C.) bithynensis; 27-28 - Ph. (Coptosiella) antoniae; 24-24 - total view; 28-29 - apical sclerits.

Рис. 24-29. Эндофаллус Coptosia and Coptosiella subgen.n.: 24 - Ph. (Coptosia) albovittigera; 25, 29 - Ph. (C.) compacta; 26 Ph. (C.) bithynensis; 27-28 - Ph. (Coptosiella) antoniae; 24-24 - общий вид; 28-29 - апикальные склериты. 